\title{
Trademarks, patents and the appropriation strategies of incumbents: the scope of new firm formation in European regions
}

Citation for published version (APA):

Belderbos, R. A., Kazimierczak, M., \& Goedhuys, M. (2022). Trademarks, patents and the appropriation strategies of incumbents: the scope of new firm formation in European regions. Regional Studies, 56(2), 210-226. https://doi.org/10.1080/00343404.2021.1947486

Document status and date:

Published: 01/02/2022

DOI:

10.1080/00343404.2021.1947486

Document Version:

Publisher's PDF, also known as Version of record

Document license:

Taverne

Please check the document version of this publication:

- A submitted manuscript is the version of the article upon submission and before peer-review. There can be important differences between the submitted version and the official published version of record.

People interested in the research are advised to contact the author for the final version of the publication, or visit the DOI to the publisher's website.

- The final author version and the galley proof are versions of the publication after peer review.

- The final published version features the final layout of the paper including the volume, issue and page numbers.

Link to publication

\footnotetext{
General rights rights.

- You may freely distribute the URL identifying the publication in the public portal. please follow below link for the End User Agreement:

www.umlib.nl/taverne-license

Take down policy

If you believe that this document breaches copyright please contact us at:

repository@maastrichtuniversity.nl

providing details and we will investigate your claim.
}

Copyright and moral rights for the publications made accessible in the public portal are retained by the authors and/or other copyright owners and it is a condition of accessing publications that users recognise and abide by the legal requirements associated with these

- Users may download and print one copy of any publication from the public portal for the purpose of private study or research.

- You may not further distribute the material or use it for any profit-making activity or commercial gain

If the publication is distributed under the terms of Article $25 \mathrm{fa}$ of the Dutch Copyright Act, indicated by the "Taverne" license above, 


\section{Trademarks, patents and the appropriation strategies of incumbents: the scope of new firm formation in European regions}

\section{René A. Belderbos, Michał Kazimierczak \& Micheline Goedhuys}

To cite this article: René A. Belderbos, Michał Kazimierczak \& Micheline Goedhuys (2021): Trademarks, patents and the appropriation strategies of incumbents: the scope of new firm formation in European regions, Regional Studies, DOI: 10.1080/00343404.2021.1947486

To link to this article: https://doi.org/10.1080/00343404.2021.1947486

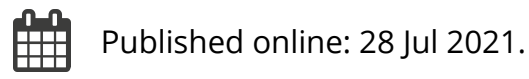

Submit your article to this journal $₫$

山 Article views: 103

Q View related articles ¿

View Crossmark data ¿

Citing articles: 1 View citing articles $\longleftarrow$ 


\title{
Trademarks, patents and the appropriation strategies of incumbents: the scope of new firm formation in European regions
}

\author{
René A. Belderbos ${ }^{\mathbf{a}}$ (1), Michał Kazimierczak ${ }^{\mathbf{b}}$ (1) and Micheline Goedhuys ${ }^{\mathbf{c}}$ (1)
}

\begin{abstract}
Analysis of the relationship between knowledge spillovers and new firm formation in 980 NUTS-3 regions at the industry level shows that regional knowledge stocks represented by patents positively influence new firm formation, but that knowledge protection and appropriation strategies of incumbents discourage it. Knowledge stocks represented by trademarks translate into higher entry rates in the absence of a pronounced appropriation strategy of incumbents or when entrants do not directly compete with the trademarking incumbents. Our findings highlight the two-sided effects of trademarks: as an indicator of product novelties as well as a potential expression of strengthened incumbent appropriation strategies.
\end{abstract}

\section{KEYWORDS}

entrepreneurship; intellectual property rights; new firm formation; entry; patents; trademarks; knowledge spillovers

JEL L26, O34, R11

HISTORY Received 29 November 2019; in revised form 3 June 2021

\section{INTRODUCTION}

Entrepreneurship and the creation of new firms are intrinsically related to economic growth and the evolution of (regional) economies (Decker et al., 2014; Geroski, 1991). High levels of new firm formation are seen as a sign of economic vitality (Lee et al., 2004), and support for entrepreneurship is ranked high on the priority lists of national and regional governments. Hence, it is important to understand the factors that are associated with changes in the rate of regional new firm formation. A growing stream of literature, in particular studies invoking the knowledge spillover theory of entrepreneurship (KSTE), has focused on the role of regional knowledge (spillovers) and innovation in providing entrepreneurial opportunities and stimulating new firm formation (Acs et al., 2009; Agarwal et al., 2010), but empirical results have been mixed (Jofre-Monseny et al., 2011; Knoben et al., 2011; Tsvetkova, 2015).

In this paper we argue that prior ambiguous results may be due to a lack of recognition that incumbents not only create knowledge but also have incentives to appropriate knowledge and innovation, thereby aiming to discourage or impede entrants from deriving benefits from local knowledge stocks. Variation in appropriation strategies of incumbent firms will affect new firm formation patterns, rendering the relationship between knowledge stocks and entry more difficult to identify. We argue that while patent stocks as an indicator of knowledge creation foster new firm formation, incumbent firms' appropriation strategies focusing on internal exploitation of knowledge reduces it.

The creation of trademarks has been acknowledged as an indicator of (novel) product introductions, which may serve as a measure identifying innovative activities beyond those measured by patents (Block et al., 2021; Castaldi, 2019; Mendonça et al., 2004). As such, trademark stocks may encourage new firm formation. On the other hand, trademarks may be used by incumbents to increase entry costs for new firms and to shield incumbent firms from effective competition in order to maintain a first mover advantages (Arora et al., 2016), as incumbents' brands and reputation render it more difficult for entrants to build their market position (Spulber, 2006). We argue that the influence of trademarks on new firm formation crucially depends on underlying appropriation strategy of

\section{CONTACT}

${ }^{\mathrm{a}}$ Rene.belderbos@kuleuven.be

KU Leuven, Leuven, Belgium; Maastricht University, Maastricht, the Netherlands; and UNU-MERIT, Maastricht, the Netherlands.

${ }^{b}$ (Corresponding author) michal.kazimierczak@euipo.europa.eu

European Union Intellectual Property Office, Alicante, Spain; and UNU-MERIT, Maastricht, the Netherlands.

'@Goedhuys@merit.unu.edu

UNU-MERIT, Maastricht, the Netherlands. 
incumbent firms. If trademarking is employed by incumbents with a strong appropriation strategy they are likely to strengthen the effectiveness of appropriation (Rujas, 1999; Thoma, 2015) and may reduce new firms' opportunities to exploit knowledge spillovers. In the absence of a strong appropriation strategy of incumbents, trademarks on new products and services may signal spillover opportunities leading to higher new firm formation levels.

Empirically, we examine the salience of these patterns in an analysis of new firm formation across 230 NACE-4 manufacturing industries and 980 regions in Europe (NUTS-3). Our research builds on a unique and detailed dataset combining information on firm formation (ORBIS), European patents (PATSTAT) and the national trademark registries of 12 European Union (EU) member states. We measure appropriation strategies as the internal exploitation of technological knowledge by incumbents through incumbent self-citations of the patented knowledge they create (Belderbos \& Somers, 2015; Zhao, 2006).

Estimating robust variance Poisson models of new firm formation with time, NACE-4 and NUTS-3 fixed effects, we confirm a consistent positive relationship between new firm formation and incumbents' patent stocks, and a negative relationship between new firm formation and incumbents' focus on appropriation through the internal exploitation of knowledge. The influence of trademark stocks is moderated by incumbents' appropriation strategy. The latter patterns are appreciably strengthened if it concerns the formation of new innovative firms with their own patenting or trademark activity.

Our findings are consistent with the notion that new firms benefit from incumbents' innovation activities in exploiting new market niches while avoiding head-on competition with aggressive incumbents. They highlight the two-sided effects of trademarks as an indicator of product novelties as well as a potential expression of strengthened incumbent appropriation strategies. Our paper contributes to the literature on regional new firm formation and entrepreneurship by reconciling earlier ambiguous results on the role of patents and trademarks and bringing in incumbent appropriation strategies as a key driver and as moderator of these relationships.

\section{THEORY AND HYPOTHESES}

Traditionally, understanding the determinants of new firm formation has been at the core of the industrial organization literature and the relationship between innovation and entrepreneurship has been at the heart of this debate. In industrial organization, entry is seen as being triggered by a level of profitability in excess of the long-run equilibrium (Geroski, 1991). While empirical studies found that entry rates are indeed relatively high in fast-growing and profitable industries and relatively low in industries with high capital requirements (Lipczynski et al., 2005) or in which incumbents have absolute cost advantages, entry rates are hard to explain by usual measures of entry barriers and profitability (Geroski, 1995).
Evolutionary economics provides more insights into the processes underlying innovation, entrepreneurship and economic dynamics (Dosi, 1988; Malerba, 2007; Nelson \& Winter, 1982). In this respect, evolutionary approaches to entrepreneurship have emphasized the long-term dynamics in industries, with new and disruptive knowledge creation leading to new firms driving out incumbents (e.g., Louçã \& Mendonça, 2002; Orsenigo, 2018). At the same time, as argued by the KSTE, new firm formation is triggered by entrepreneurial opportunities created by incumbent firms, when new knowledge is created by incumbent firms that is commercially not exploited by them (Acs et al., 2009; Agarwal et al., 2007).

A different stream of recent research has examined types of knowledge-generating spillovers and their measurement, focusing in particular on trademarks as an alternative indicator of innovation activities beyond patents. The literature on trademarks is nascent, which is at least partially due to the lack of a comprehensive theory explaining firms' rationale for filing for trademark protection and their associated trademarking strategies (Castaldi, 2020). Research on trademarks has been developed in three distinct research domains: industrial organization, innovation and entrepreneurship (Castaldi et al., 2020). Each perspective focuses on different motives for trademark protection: to raise entry barriers and secure market positions, to appropriate returns from innovation, and to attract resources. Research on the use of trademarks has suggested that trademark activity can be considered as an indicator of new product and service introductions indicating broader innovative activities and knowledge creation not captured by patents (Block et al., 2021; Castaldi, 2019; Mendonça et al., 2004; Sáiz \& Zofío, 2021). Studies have, for instance, found that trademarks serve as an indicator of service innovation (e.g., Flikkema et al., 2019; Gotsch \& Hipp, 2012). Trademarks may have advantages in capturing particular innovative activity such as innovation in small firms and service innovation (Castaldi, 2019; Flikkema et al., 2014; Schautschick \& Greenhalgh, 2016).

Below we take a KSTE perspective to develop hypotheses on the roles of regional patent and trademark stocks as joint determinants of new firm formation in manufacturing industries. We crucially bring in the appropriation perspective on incumbent firm behaviour, which complements the knowledgecreation perspective that focuses on knowledge spillovers and entrepreneurial opportunities. Innovating incumbent firms creating local knowledge stocks may at the same time use strategies to increase appropriation and the returns from their innovations. Such knowledge-appropriation strategies reduce knowledge spillovers and discourage entry. At the same time, we argue that incumbent knowledge-appropriation strategies can alter the influence of trademarking from accommodating entry, through the dynamics of new product development, to discouraging entry, through the formation of strong entry barriers. 


\section{Local patent stocks}

The role of knowledge pools is one of the major factors facilitating new firm creation according to the KSTE theory, which argues that knowledge spillovers from incumbents play a central role in the emergence of entrepreneurial opportunities (Acs et al., 2009; Agarwal et al., 2007). KSTE posits that 'entrepreneurial opportunities do not appear to be exogenous but are rather systematically created by a high presence of knowledge spillovers' (Acs et al., 2009, p. 23). The creation of new firms is directly linked to the knowledge created but not commercially exploited by incumbent firms (Acs et al., 2013). Uncertainty, information asymmetries and high transaction costs inherent to knowledge creation tend to be associated with divergent views regarding the value of technologies and ideas, facilitating the pursuit of unexploited opportunities with commercial potential (Acs et al., 2009; Christensen, 2012; Malerba, 2007). Given the uncertain prospects of novel technologies and the limitations to firms' resources, incumbents leave open some business opportunities related to knowledge for exploration and exploitation by other economic agents, thereby fostering the entry of new firms.

Geographical proximity between firms has been broadly acknowledged to facilitate knowledge spillovers (e.g., Belderbos \& Mohnen, 2020; Griffith et al., 2009). Transmission and accumulation of tacit knowledge requires direct and regular interpersonal contacts (Maskell \& Malmberg, 1999) and increased interactions between employees cause ideas to be disseminated among neighbouring firms (Glaeser et al., 1992). The experiential and social nature of knowledge transmission and learning drive knowledge accumulation towards domains related to those already present in the vicinity. Spatial proximity is therefore also an important factor conditioning the direction of entrepreneurial search and selection.

The stock of locally invented patents is considered a key indicator of locally created (technological) knowledge (e.g., Belderbos \& Somers, 2015; Jofre-Monseny et al., 2011; Knoben et al., 2011; Tsvetkova, 2015) capturing technology-based business opportunities. Extant studies, employing patent citation analysis, have found ample evidence that locally invented patents induce geographically bounded knowledge spillovers, with other local firms building on the locally created technological knowledge (e.g., Belderbos \& Mohnen, 2020; Belenzon \& Schankerman, 2013; Jaffe, 1986; Jaffe et al., 1993).

Technological relatedness is an important aspect steering the direction of knowledge spillovers, as the possibilities to diversify into new technologies and industrial sectors depend on existing portfolios of technological knowledge (Boschma, 2017; Boschma et al., 2015; Kogler, 2017). The need for a shared sphere of knowledge and competences (Frenken et al., 2007) and cognitive proximity (Qian et al., 2013) for effective knowledge spillovers make that most spillovers occur within the confines of the same industry (Boschma, 2017; Boschma et al., 2015; Kogler, 2017). Hence, the larger the local stock of patents in a region and industry, the more likely it is that knowledge spillovers and unexploited technological opportunities provide attractive entry possibilities for new firms. This leads to the following hypothesis:

Hypothesis 1: Patented knowledge stocks: The stock of patents in a region and industry has a positive influence on new firm formation in that region and industry.

\section{Knowledge-appropriation strategies}

Less well recognized in the KSTE and regional innovation literatures is that incumbent firms not only create knowledge, but that they will also aim to shield their knowledge and increase appropriation to ensure commercialization and return on investments. While innovation and spillovers are likely to create entrepreneurial opportunities for new entrants, incumbent firms also deploy appropriation strategies to limit the exploitation of technological opportunities by entrants (Akcigit \& Ates, 2021; Leten et al., 2016) and to maximize their own exploitation of technological knowledge (Teece, 1986). Given the importance of knowledge and innovation for incumbent firms' competitiveness, they have incentives to shield their knowledge and increase appropriation. They may aim to deter direct rivals and potential entrants from encroaching on their markets (Belderbos \& Somers, 2015; Bloom et al., 2013). Innovating incumbents may use various strategies to limit the extent of knowledge flowing to competitors or potential entrants (Levin et al., 1987). One way of increasing appropriation is the use of intellectual property rights such as patents (Scotchmer, 2004). Firms can use patent enforcement and litigation aggressively to protect their knowledge and limit competition (e.g., Agarwal et al., 2009).

The creation and rationale of patent systems rest on two contrasting objectives: providing the means for knowledge appropriation and therewith increasing the incentives to invest in innovation, but also fostering knowledge dissemination, by publishing inventions in detail and providing opportunities for dissemination of ideas on which further inventions can build (e.g., Guellec \& Van Pottelsberghe de la Potterie, 2007). Hence, if patents are used as indicators for local knowledge created by incumbents and providing entrepreneurial opportunities, it is important to at the same time capture the appropriation strategy of local incumbents for such patented knowledge, which is likely to reduce knowledge spillovers.

The literature has suggested that an important strategy firms can deploy to reduce knowledge outflows is to focus on the internalization of research and development $(\mathrm{R} \& \mathrm{D})$ and technology development, by building a strong internal R\&D organization and, for multi-location firms, building strong cross-unit internal linkages through cross-unit collaboration (Akcigit \& Ates, 2021; Alcacer \& Zhao, 2012; Belderbos et al., 2021; Belderbos \& Somers, 2015; Zhao, 2006). Alácer and Zhao (2012) show that incumbent firms, confronted with collocated rival firms in a local knowledge cluster, pursue such cross-unit collaboration to protect knowledge, and that such behaviour is 
associated with reduced knowledge outflows to the collocated firms. Belderbos and Somers (2015) find that selfcitations by regional innovation leaders in European regions render locating in these regions for foreign firms less attractive, due to the more limited knowledge spillovers that can be obtained from the innovation leaders' R\&D activities.

Efforts to limit knowledge spillovers and build internally on technological knowledge lead to a pattern of selfcitations of the incumbent firms' patents (Kim, 2015). Self-citations are associated with increased firm market value due to the apparent greater in-house strength of the firm in protecting and appropriation knowledge through commercial exploitation (Belderbos et al., 2014; Belenzon, 2012). In the presence of strong incumbents aggressively defending their market position through such knowledge protection and appropriation strategies, new entrants may benefit less from knowledge spillovers and may choose alternative industries or regions, avoiding direct competition with the incumbents.

It follows that the strength of local incumbents' appropriation strategy for knowledge embedded in patents in the industry has a negative influence on new firm formation in that industry, suggesting the following hypothesis:

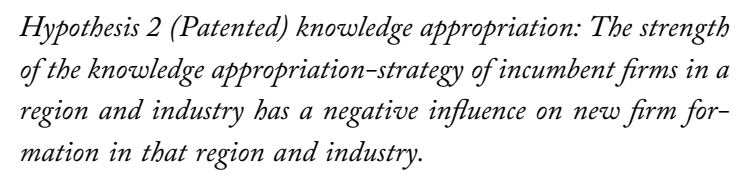

\section{Local trademark stocks and knowledge appropriation}

The use of trademarks by incumbents can both reflect attempts to raise entry barriers and product and service innovations not measured by patents, leading to ambiguous consequences for opportunities for new firm formation. On the one hand, the filing of new trademarks reflects the introduction of novel offerings on the market and an attempt to persuade consumers that these offerings address their needs, not yet covered by existing products or services (Mendonça et al., 2004). In this regard, they reflect innovative activities that may provide ideas for related market opportunities for new entrants.

On the other hand, the use of trademarks by incumbents can also reflect attempts to raise entry barriers. Branding is a key element for differentiation of a firm's products from competitors and providing information about the quality and 'meaning' of its products (Belleflamme \& Peitz, 2010). Brands can be critical to the long-term success of an innovation as it can shield incumbents from increased competition in the product market and prevent the slide of the products into commodity status (Aaker, 2007). Trademarks provide a legal protection for the substantial expenditure required to build brands and can help small and medium-sized enterprises (SMEs) to protect their niche on the market (Block et al., 2015).
Loyalty to existing brands and reputation of incumbents are an important barrier to entry and therefore product differentiation or brand proliferation are seen as entry-deterring strategies (Aaker, 2007; Lipczynski et al., 2005; Spulber, 2006). Trademarks may be used by incumbents to increase market share at the cost of rivals and to increase entry costs for new firms (De Faria \& Sofka, 2010). Empirical evidence suggests that a firm's market value increases in its trademark portfolios (Sandner \& Block, 2011) and that trademarks related to product launches can lead to a market stealing effect (Greenhalgh \& Rogers, 2012).

There is evidence that trademarks can enhance the appropriation potential of patent protection as well (Llerena \& Millot, 2020; Rujas, 1999; Thoma, 2015) if patents and trademarks are used in conjunction. Trademarks can aid the commercialization potential of firms' innovations and raise additional barriers to competing firms to imitate. Drivas (2020) finds that trademarks measure marketing and commercialization activities for exploitation of technological innovations. Crass (2014) shows that the use of brands is associated with a $35 \%$ increase in sales of innovative products and Arora et al. (2016) finds that the use of trademarks helps incumbents prolong their technologybased first mover advantage on the market.

In particular if incumbents have a pronounced appropriation strategy, their use of trademarks is more likely to be geared towards raising barriers for entrants. Not only is technological knowledge internalized, the products and processes based on that knowledge are further protected through trademarks and brand reputation, leaving entrants without knowledge spillovers and higher entry barriers. This suggests a negative moderation effect of incumbent appropriation strategy on the influence of trademarks on new firm formation. While the stock of trademarks, as an indicator of new product introductions, may have a positive impact on new firm formation in the absence of a pronounced appropriation strategy of incumbents, if employed by patenting incumbents aiming to enhance appropriation and commercialization in the product market, the influence of trademarks is most likely to be negative. This leads to the following hypothesis:

\footnotetext{
Hypothesis 3: Trademarks and knowledge appropriation: the influence of the number of trademarks in a region and industry on new firm formation in that region and industry depends on the strength of the appropriation strategy of incumbent firms. With a weak appropriation strategy, the influence is positive, but with a strong appropriation strategy, the influence is negative.
}

\section{DATA, VARIABLES AND METHODS}

For our research design detailed geographical, industrial and firm-level data are required across regions and countries. We draw on the ORBIS dataset of Bureau van Dijk and combine this with patent and trademark data. We use data on nearly 20 million firms active in 12 
EU countries (AT, BE, DE, DK, ES, FR, GB, HU, IT, LT, NL and PT) covering the period 2002-09. The main criteria for the selection of countries were the availability of data on national trademarks and adequate coverage of company records in ORBIS. ORBIS is the most complete source of micro-data currently available across countries and has become the standard data source for micro-data, though smaller firms may be underrepresented in countries that have less stringent rules regarding financial data provision. Drawing on ORBIS, we construct measures of new firm formation and the number of incumbents across fine grained geographical areas (NUTS-3 regions) in the 12 countries and across fine grained industries (NACE-4 industries). This information allows us to bring the data to our focal level of analysis: the various NUTS-3-NACE-4 combinations.

We combine ORBIS data with patent and trademark data by matching patent and trademarks to firms. We developed an algorithm, based on Magerman et al. (2006), to establish unique matches between firms in ORBIS and applicant names in the patent and trademark registers. ${ }^{1}$ We use European Patent Office (EPO) patents (drawn from PATSTAT) to calculate measures of knowledge stocks. The focus on EPO patents stems from the popularity of EPO applications among European firms and from the rich information regarding addresses of inventors, which is much broader and of higher quality in European patent applications compared with national patent applications. For trademarks we use national data of trademark registration in the 12 countries. In contrast to patents, for trademarks national applications have a better coverage, while European trademarks are much less frequently used. After assigning patents and trademarks to firms, we calculate patent and trademark stocks per NUTS-3 and NACE- 4 based on the region and industry of each matched firm. In case of patents, the location of innovative activity is determined based on the location of the inventors, which allows for a better identification of the location of innovative activities than an assignment based on patent assignee address would provide (e.g., Basberg, 1987).

The database covers 980 NUTS-3 regions and 230 NACE-4 manufacturing industries, during the eightyear period 2002-09. After dropping a limited number of observations with missing values for control variables, the database still has a large number of observations $(1,727,830)$.

\section{Focal variables}

The dependent variable in our models is the number of newly established manufacturing firms in year $t$ in a NUTS-3 region and NACE-4 industry. The NACE four-digit level is considered to represent the product level, with firms active in these industries likely to be direct competitors (Bloom et al., 2013). New entrants are identified based on the establishment date, available at ORBIS, for the period 2002-09.

Key explanatory variables of interest are the presence of local patent and trademark stocks, and appropriation strategy. We calculate the patent stock in the NUTS-3 region and NACE-4 industry by using the perpetual inventory method (e.g., Guellec \& Van Pottelsberghe de la Potterie, 2004):

$$
\mathrm{PS}_{r, j, t}=\mathrm{P}_{r, j, t}+(1-\delta) * \mathrm{PS}_{r, j, t-1}
$$

where $\mathrm{PS}_{r, j, t}$ denotes the patent stock in NUTS-3 region $r$, NACE-4 industry $j$ and year $t, \mathrm{P}_{r, j, t}$ is the number of new patents applied for by firms located in NUTS-3 region $r$ and active in NACE-4 industry $j$ in year $t$, and $\delta$ is the deprecation rate of patented knowledge. We adopt a constant depreciation rate of $15 \%$, as is common in research on patents and R\&D (Bloom et al., 2013; Hall et al., 2005; Lychagin et al., 2016).

We account for the possibility that knowledge spillovers extend beyond the borders of the NUTS-3 region by using a distance weighted measure of patent stocks, capturing patents invented in proximity to the focal NUTS-3 region with a maximum of $200 \mathrm{~km}$. The latter threshold is informed by findings of Bottazzi and Peri (2003) and Belenzon and Schankerman (2013), who concluded that spillovers decay with distance, with very little evidence of spillovers left beyond a distance of 200-300 $\mathrm{km}$. Hence, we augment the focal NUTS-3 patent stock with the weighted count of patent stocks in adjacent regions, applying weights based on the inverse of geographical distance from the centroid of the focal NUTS3 region (Belderbos et al., 2013; Lychagin et al., 2016). The patent stock measure is therefore the sum of the stock from the focal NUTS-3 region and the weighted mean of relevant patent stocks from regions lying up to $200 \mathrm{~km}$ from the focal NUTS-3 centroid, where weights depend on the distance from focal NUTS-3.

The indicator of appropriation strategy of incumbents in the industry and region is based on forward self-citations of patents of the incumbents. Self-citations of a firm's patents within and across units of the firm, indicate an internal orientation of $\mathrm{R} \& \mathrm{D}$ guarding against knowledge outflows and the in-house exploitation of technological knowledge (Akcigit \& Ates, 2021; Alcacer \& Zhao, 2012; Belderbos \& Somers, 2015; Zhao, 2006). Firms exhibiting such self-citations have a stronger technology appropriation strategy translating into higher market value (Belderbos et al., 2014; Belenzon, 2012). We operationalize this by measuring the stock of incumbents' patents in an industry and region that exhibit such selfcitations. In order to identify self-citations, we rely on patent allocation to firms at the consolidated level, drawing on ORBIS; hence self-citations can be by other units of the firm located in different countries or regions. The self-cited patent stock is measured in the same manner as the patent stock variable, with the perpetual inventory method and covering a $200 \mathrm{~km}$ radius of the focal region. Appropriation strategy is the stock of local industry patents with at least one self-citation.

For the trademark stock in the focal industry and region we follow a similar procedure, with the exception that there is no depreciation rate available. Instead, trademark 
stocks are updated calculating trademarks that are in force and not expired. Exact expiration dates are available for the UK, Germany and Hungary. For other countries we assumed that trademarks expire after the average number of years until expiration in these three countries, which is about 20 years.

Hypothesis 1 suggests a positive effect of the patent stock in the focal industry and region. Hypothesis 2 suggests a negative effect of incumbents' appropriation strategy. Since simultaneous inclusion of the focal industry patent stock and the focal industry self-cited patent stock would lead to multicollinearity, we test Hypothesis 2 by scaling the stock of self-cited patents by the total patent stock. Hypothesis 3 predicts a negative interaction effect of the trademark stock in the focal industry and the selfcited patent stock variable.

\section{Control variables}

New firm formation can also be affected by patent and trademark stocks in other industries. Patent and trademark stocks are only expected to be relevant for potential entrants into a focal industry though if there is technological and cognitive proximity, facilitating the understanding, processing and integration of new knowledge, and the absorptive capacity to identify entrepreneurial opportunities (Qian et al., 2013). Frenken et al. (2007) argue that for variety in knowledge to foster growth or entry, there should be some shared sphere of knowledge and competences, that is, (knowledge) variety should be related. Hence, we include the patent stock in technologically related industries in the industry and region, which is the sum of the knowledge stocks of non-focal industries weighted by their relatedness to the focal industry. We constructed a technology relatedness matrix between manufacturing industries at the NACE four-digit level, making use of our data on firms' patents and their industry affiliation. We follow the logic that industries are more related if the technologies represented in the patent stocks of firms active in these industries are more similar. We use the Jaffe method (Jaffe, 1986) and calculate the Euclidian distance between two industries based on the shares of the various patented technology subclasses of the international patent classification represented in the patent stocks of the industries. Our data enabled us to construct a detailed inter-industry technology relatedness matrix at the granular NACE four-digit level. The elements of the matrix are used as weights to calculate the stock of patents in (technologically) related industries for each region and industry. To be consistent with the variables on the patent and trademark stocks in the focal industry, we similarly construct the trademark stock in technologically related industries and incumbent appropriation strategy in technologically related industries. In addition, we include a separate dummy variable to control for a lack of patents in the focal industry.

We employ a broad set of other control variables, drawing on the comprehensive review of variables used in location choice models by Arauzo-Carod et al. (2010). We include two variables describing features of the local innovation system (Audretsch \& Fritsch, 2002; Winter,
1984). The share of young firms in patenting in year $t$ in the NUTS-3/NACE-4 represents a greater dynamism in the region and industry and may imply greater potential for knowledge sourcing. It also enables to measure to what extent innovative young firms with new technologies rather than older incumbents are stimulating entry and industry evolution (Louçã \& Mendonça, 2002; Orsenigo, 2018). We define a firm as young when in year $t$ it is five years old or younger, based on its establishment date in the ORBIS database. Similarly, a greater contribution of universities to regional knowledge stocks may be beneficial for entrants, as universities are less inclined to fence-off their knowledge. We include the variable share of universities in patenting, measured at the NUTS-3 level. ${ }^{3}$

We also include control variables for the influence of agglomeration economies. The omission of this factor may lead to an overestimation of the role of the regional knowledge base (Audretsch \& Feldman, 1996; Greenstone et al., 2010; Knoben et al., 2011). We control for the number of incumbents at the NUTS-3/NACE-4 to capture the size of the industry agglomeration at the regional level. The Number of incumbents is the natural logarithm of the number of incumbent firms active in the focal NACE4 industry and NUTS-3 region, as retrieved from ORBIS. In addition we control for agglomeration externalities due to the presence of buyers and suppliers (Alcacer \& Chung, 2014; Dumais et al., 2002; Glaeser \& Kerr, 2009). Supplier fit is the degree to which the structure of the local industries is in line with the supply needs of the focal industry, that is, the degree to which the specialization pattern of the NUTS-3 region across industries represents the needs of the focal industry. We use national input-output tables from Eurostat (available at the NACE two-digit level) to establish focal industry supply needs. We distribute industry employment data from national accounts across NUTS-3 regions in proportion to the number of incumbent firms in the regions. Following Dumais et al. (2002) we define supplier fit using the following formula:

$$
\text { supplierfit }_{r, i, t}=\sum_{j \neq i} I_{j, i} * \frac{E_{j, r, t}}{E_{r, t}}
$$

where $I_{j, i}$ is the share of industry $i$ 's inputs that are sold by industry $j$ from the input-output table; $E_{j, r, t}$ is employment of industry $j$ in region $r$ in year $t$, and $E_{r, t}$ is total employment in region $r$. Supplier fit increases if the region exhibits an employment pattern across industries that is resembling the mix of inputs required by the focal industry. Buyer fit is calculated in an identical manner, but uses output coefficients and employment data relating to the presence of buyer industries.

We complement the model with a set of industry and region controls. As growth prospects are important for entrants, we include a measure of industry output growth measured as the difference in the log of output in the years $t-2$ and $t-1$. Data restrictions impose that this is measured yearly at the country and NACE two-digit level. GDP per capita (in logs) and GDP per capita growth, measured as the difference in the log of GDP per capita in 
years $t-2$ and $t-1$ at the NUTS-3 level, are measured in purchasing power standards and indicate regional purchasing power (growth) and market sophistication. Urbanization is captured by Population density (natural logarithm of the number of inhabitants per $\mathrm{km}^{2}$ at the NUTS-3 level) in year $t$. The unemployment rate (unemployed persons as a percentage of the economically active population), at the NUTS-2 level in year $t$, controls for a potential influence of necessity entrepreneurship on new firm formation. Finally, the education level in the region is included through the variable secondary and tertiary education $\%$ in year $t$, measuring the share of educated persons in the region, with education defined as upper secondary, post-secondary non-tertiary and tertiary education, corresponding to the levels 3-8 of the International Standard Classification of Education (ISCED).

The focal variables and the agglomeration variables are lagged by one year, as knowledge spillovers take time to reach other firms and start-ups, and to exclude potential spurious correlation due to patenting and trademarking entrants. In the Poisson model that we use for estimating the relationships, variables expressed in natural logarithms can be interpreted as elasticities.

\section{Econometric specification}

The dependent variable (number of firms entering the market in the NUTS-3 region and NACE-4 industry in year $t$ ) is a count variable that takes only non-negative integer values. In case of modelling such data, linear regression modelling is inadequate (Cameron \& Trivedi, 2005). The proper modelling approach for count variables is based on a Poisson distribution, which is parametrized in terms of a single parameter $(\mu)$ (Cameron \& Trivedi, 2005), assuming equi-dispersion: the equality of mean and variance. However, our data are characterized by overdispersion. The measure of variance in the dependent variable is much larger than the mean. The Pearson statistic calculated for the main model is 1.055 , which confirms that the model is moderately overdispersed. The consequences of overdispersion are comparable with the failure of the assumption of homoscedasticity in the linear regression model (Cameron \& Trivedi, 2005): whereas the coefficients of the model are consistent, standard errors can be deflated. The preferred strategy in such circumstances is to account for the bias in the standard errors by estimating these in robust terms (Hilbe, 2014). We apply robust clustering at the NUTS-3 and NACE-4 level to address this and to also ensure robustness with respect to within-region correlation. ${ }^{4}$

The unit of observation of our dependent variable is the NUTS-3 region -NACE four-digit industry combination. For many such combinations we observe zero entries with no existing incumbents, and we also observe entries into industries with previously no establishments in the region. Following Glaeser and Kerr (2009), we therefore control for time-invariant industry and region influences by including separate sets of fixed effects for the NUTS-3 region, the NACE four-digit-level industry, and years.

\section{RESULTS}

Table 1 presents the descriptive statistics, and Table 2 shows correlations between the variables. The average number of new firms at the fine grained NUTS-3NACE-4 level is 0.19 , with the number of new firms ranging between zero and 307. Trademark stocks in the focal industry are larger than patent stocks in the focal industry. Patent and trademark stocks in technologically related industries are substantially larger because they aggregate over multiple industries. By and large, correlations between the variables do not raise multicollinearity concerns.

Table 3 presents the results of the Poisson model relating new firm formation at the NUTS-3 and NACE-4 level to patent and trademark stocks. The first column shows the results of a model with patent stock variables only. Model 2 adds the measure of incumbents' appropriation strategy to test hypothesis 2 . In model 3 we add trademark stock variables, and in model 4 the interaction between trademark stock and appropriation strategy. Whereas models 1-4 focus on general new firm formation, model 5 focuses on the subset of innovating new firms. As shown in the bottom rows of Table 3, likelihood ratio tests show that the goodness of fit significantly improves for the more complex models.

The results of model 1 suggest that the positive association between the patent stock in the focal industry and new firm formation is relatively weak and statistically significant only at the $10 \%$ significance level. However, subsequent models reveal that this relationship becomes stronger once we account for the appropriation efforts of incumbents. The estimated coefficient in the most complete specification in model 4 shows that a $10 \%$ increase in the patent stock is associated with a $0.52 \%$ increase in new firm formation. These results confirm Hypothesis 1. Model 2 reveals a negative and significant association between incumbents' appropriation strategy and new firm formation, as predicted by Hypothesis 2. The estimated coefficients for appropriation strategy in models 2-4 suggest a similar elasticity as that for the patent stock in the industry in model 4.

In model 3, the coefficient of the trademark stock variable fails to reach statistical significance, while the negative and statistically significant coefficient of the interaction variable between the trademark stock and appropriation strategy confirms that the influence of trademarks in a region and industry on new firm formation indeed depends on the strength of the appropriation strategy of incumbent firms. The implied elasticity of new firm formation with respect to the trademark stock for different levels of appropriation strategy is shown in Figure 1. In regions and industries with a weak appropriation strategy, there is a positive, but statistically insignificant elasticity of new firm formation with respect to the trademark stock. The elasticity turns negative when appropriation strategy (the natural logarithm of the self-cited patent stock) exceeds 0.5 , which is a feature of $9 \%$ of observations in 
Table 1. Descriptive statistics.

\begin{tabular}{lcccc}
\hline & Mean & SD & Minimum & Maximum \\
\hline New firm formation (NUTS-3/NACE-4) & 0.191 & 1.267 & 0 & 307 \\
Innovating new firm formation (NUTS-3/NACE-4) & 0.014 & 0.141 & 0 & 17 \\
Patent stock (NUTS-3/NACE-4) (In) & 0.262 & 0.567 & 0 & 9 \\
Appropriation strategy (NUTS-3/NACE-4) (In) & 0.147 & 0.42 & 0 & 8 \\
Trademark stock (NUTS-3/NACE-4) (In) & 0.652 & 0.886 & 0 & 8.392 \\
Patent stock, technologically related industries (NUTS-3/NACE-4) (In) & 2.857 & 1.165 & 0 & 8.388 \\
Appropriation strategy, technologically related industries (NUTS-3/NACE-4) (In) & 2.147 & 1.090 & 0 & 7.715 \\
Trademark stock, technologically related industries (NUTS-3/NACE-4) (In) & 4.561 & 1.268 & 0 & 10.116 \\
No patents (dummy) & 0.261 & 0.439 & 0 & 1 \\
Number of incumbents (NUTS-3/NACE-4) (In) & 0.776 & 1.018 & 0 & 8 \\
Share of young firms in patenting (NUTS-3/NACE-4) & 0.076 & 0.220 & 0 & 1 \\
Share of universities in patenting (NUTS-3) & 0.024 & 0.032 & 0 & 0.319 \\
Buyer fit (NUTS-3/NACE-2) & -0.002 & 0.987 & -1.924 & 7.296 \\
Supplier fit (NUTS-3/NACE-2) & -0.005 & 0.931 & -2.206 & 17.498 \\
Industry output growth (country/NACE-2) & 0.023 & 0.071 & -0.331 & 0.857 \\
GDP per capita (NUTS-3) (In) & 9.988 & 0.331 & 8.455 & 11.316 \\
GDP per capita growth (NUTS-3) & 0.030 & 0.040 & -0.315 & 0.343 \\
Unemployment rate (NUTS-2) & 0.077 & 0.040 & 0.018 & 0.26 \\
Secondary and tertiary education (\%) (NUTS-3) & 0.723 & 0.146 & 0.16 & 0.97 \\
Population density (NUTS-3) (In) & 5.393 & 1.265 & 1.932 & 9.964 \\
\hline
\end{tabular}

the sample. The results indicate partial support for Hypothesis 3: while the influence of the trademark stock does change sign depending on incumbent appropriation strategy and is negative at high levels of this strategy, we do not observe a clear positive influence in the absence of an appropriation strategy.

Models 1-4 also show interesting results for the patent and trademark stocks in technologically related industries. We observe a generally positive effect of the patent stock in technologically related industries on new firm formation, with higher elasticities than those observed for the focal industry patent stock. In contrast with focal industries, appropriation strategy of incumbents in technologically related industries has a positive, rather than negative influence on new firm formation. Trademark stocks in technologically related industries have a strongly significant positive influence on new firm formation. Although this effect is weakened in technologically related industries with a stronger appropriation strategy, it can be calculated that the trademark stock effect never becomes negative. The results suggest that trademark and patent stocks in technologically related industries are much more accommodating for new firm formation than patent and trademark stocks in the focal industry of such new firm formation. We posit that this is due to the limited direct rivalry between the new firms and incumbent in technologically related industries. If entry is in product markets in which the incumbents are not active, new firms are less likely to challenge incumbents' market share and profitability. Incumbents have fewer incentives to shield their knowledge and to discourage entry, with appropriation strategies most likely to target entrants in the focal industry. This may give opportunities to benefit from knowledge spillovers to new firms in other industries, with the knowledge, due to its technological relatedness, still very relevant to the new firms.

Results for the other control variables indicate that new firm formation tends to be lower in industries and regions without patent activity. The number of incumbents in the focal region and industry has a strong positive influence on new firm formation, with an elasticity just above 0.9. New firm formation is also positively associated with the share of young firms in patenting in the focal industry, in line with the evolutionary view of regional economic innovation and industrial dynamics (e.g., Louçã \& Mendonça, 2002). On the other hand, a higher contribution of universities to the patent stocks in the region does not translate into higher levels of new firm formation, It may be that patents, if they are applied for by universities, may be further away from the commercialization phase (e.g., Arora et al., 2020) and less directly relevant for new firms looking for opportunities to benefit from knowledge spillovers. New firm formation is also significantly and positively related to GDP per capita growth and industry growth. Population density is negatively related to new firm formation, which may be due to the space requirements for manufacturing entries.

\section{New innovating firm formation}

We further examine the relationship between knowledge creation, appropriation and new firm formation by focusing the analysis on innovating new firms, as observed from their filing for patents or trademarks after entry. This analysis will exclude the possibility that necessity 


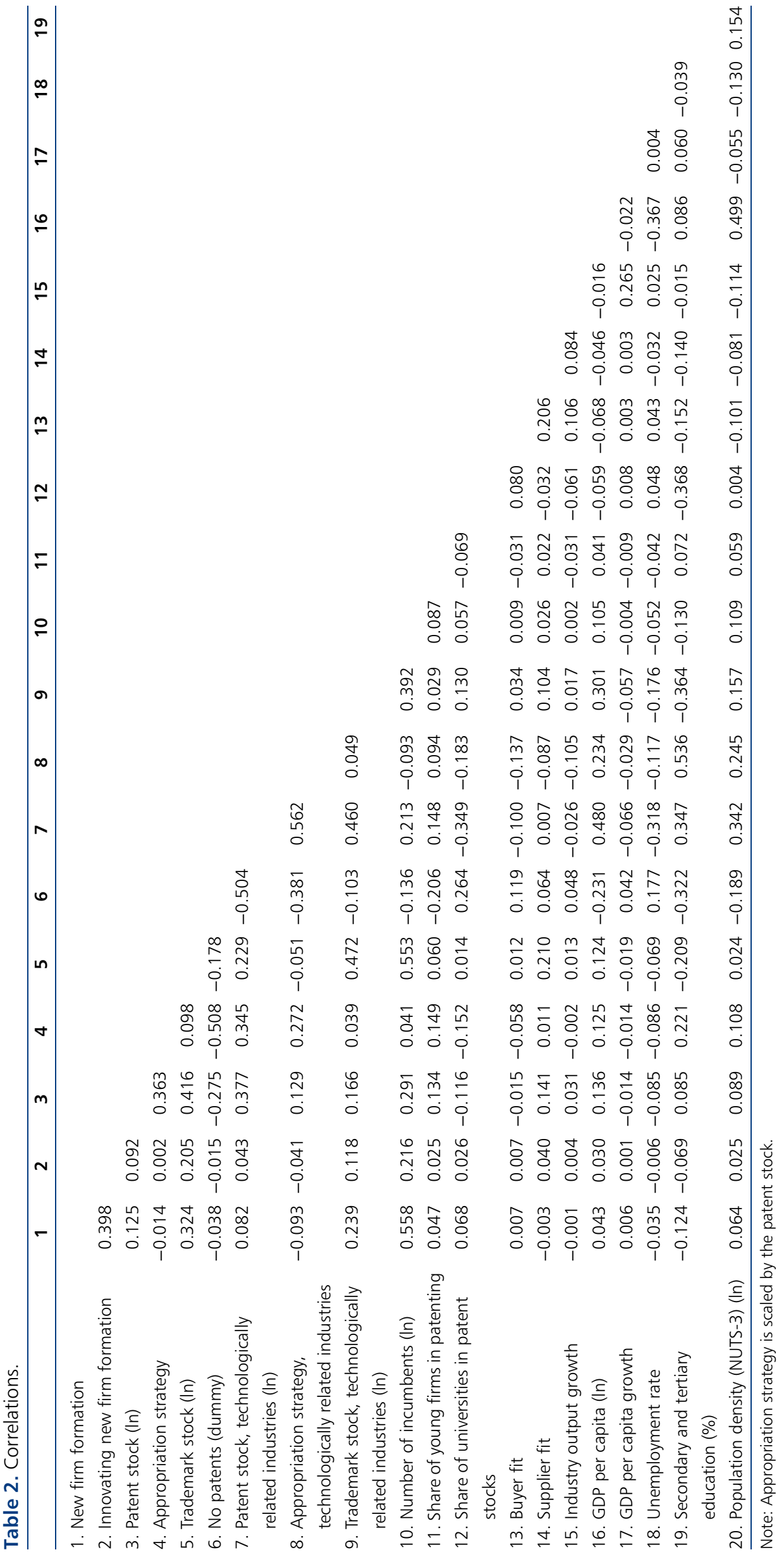


entrepreneurs, driven by adverse economic conditions, are counted among the entrants (Fairlie \& Fossen, 2018). We may expect that knowledge related factors are of greater importance to innovating entrepreneurs.

The last column in Table 3 presents the results of estimations with the number of innovating new firms as the dependent variable. The negative influence of appropriation strategy is not statistically significant. What also stands out is that the coefficients of trademark and patent stocks in the focal industry are much larger than the coefficients estimated for general new firm formation. The coefficient for the focal industry patent stock suggests that a $10 \%$ increase in this stock leads to a $1.57 \%$ increase in the number of entries. For the trademark stock this effect is even larger at $3.19 \%$, if appropriation strategy is held at zero. The negative interaction effect between the trademark stock and appropriation strategy of incumbents is still observed. Figure 2 shows the changing magnitude of the elasticity of new innovating firm formation with respect to the trademark stock. A significantly positive elasticity turns negative in industries and regions with strong appropriation strategies, but this negative elasticity never becomes significant. These results overall suggest strong support for the KSTE view of entrepreneurship, with substantial positive influences of both patent and trademark stocks in the focal industry. Apparently, new firms that are able to apply for patents and trademarks themselves have the resources and absorptive capacity to benefit from spillover and bypass the appropriation efforts of incumbents.

Patent stocks in technologically related industries are again positively associated with new firm formation, while the influence of trademark stocks in technologically related industries on new innovating firm formation remains positive for most levels of appropriation strategy. Among the other control variables it is interesting to note the positive and significant effects of buyer and supplier fit, indicating a more pronounced role of agglomeration economies for innovative entries.

\section{Robustness analysis}

We estimated several alternative models to assess the robustness of our findings. First, we considered that results might be biased because for some of the NUTS-3 regions we have no information on patent and trademark stocks in surrounding regions, due to our focus on $12 \mathrm{EU}$ countries. Results were similar when we exclude 42 border regions from the analysis. Second, the role of knowledge spillovers and appropriation in regional markets may be different for de novo entries and for new firm formation linked to existing enterprises. Supplementary analysis suggested a similar overall pattern of coefficients, but a somewhat lower influence of patents and trademark stocks, which may be due to an on average lower absorptive capacity to benefit from knowledge spillover by de novo entrants. Third, we confirmed the robustness of our findings in models in which industry-region observations for which no patents or trademarks are observed were omitted. Results of these three robustness analyses when taking innovating new firms as an alternative dependent variable generally showed findings that were consistent with the results reported in model 5 of Table 3. The findings for de novo new firm formation showed a positive and significant influence of trademark stocks (for low levels of appropriation strategy) consistent with the notion that the benefits from knowledge spillovers are particularly salient for innovating new firms.

\section{CONCLUSIONS}

Our findings on the role of incumbent patent and trademark stocks on new firm formation at the detailed industry level in European NUTS-3 regions show that not only knowledge creation and knowledge spillovers, but also knowledge-appropriation strategies by incumbent firms determine new firm formation. New firm formation increases in industries and regions with larger patent stocks. However, incumbents' appropriation strategy in the focal industry, indicated by an R\&D organization emphasizing internal exploitation of knowledge to improve appropriation and commercialization, discourages new firm entry. We found no similar discouragement stemming from appropriation strategies of incumbents in technologically related industries. This suggests that new firms may avoid head-on competition with aggressive incumbents in the industry but benefit from innovation activities in technologically related industries to develop new market niches.

Although the possibility that strategic behaviour of incumbents may affect the likelihood of knowledge spillovers has been recognized in the KSTE literature (e.g., Audretsch et al., 2006; Plummer \& Acs, 2014) it has not received further attention and has not been subject to empirical testing. The absence of this consideration in prior work is a possible explanation why earlier findings on the role of regional knowledge stocks in spurring new firm formation have been mixed (Jofre-Monseny et al., 2011; Knoben et al., 2011; Tsvetkova, 2015). Our paper expands on this literature and adds new insights by bringing in appropriation strategy as a key determinant of new firm formation. The notion that the presence of (large) incumbent firms, presumably with more appropriation power, may be detrimental to regional dynamism is also evident from our finding that a higher share of young firms in industry patenting is positively related to entry. This is consistent with the evolutionary view of regional economic systems and suggests the importance of distributed knowledge generation by small firms and new entrants in generating resilience in regional industry settings (e.g., Louçã \& Mendonça, 2002).

Our research also contributes to the nascent literature on the role of trademarks in industrial dynamics and regional innovation systems. In particular, we confirmed that trademarks may be complementary to patents as indicators of regional innovation capabilities and their evolution (as shown in this special issue by Block et al., 2021; Drivas, 2020; and Sáiz \& Zofío, 2021). However, 


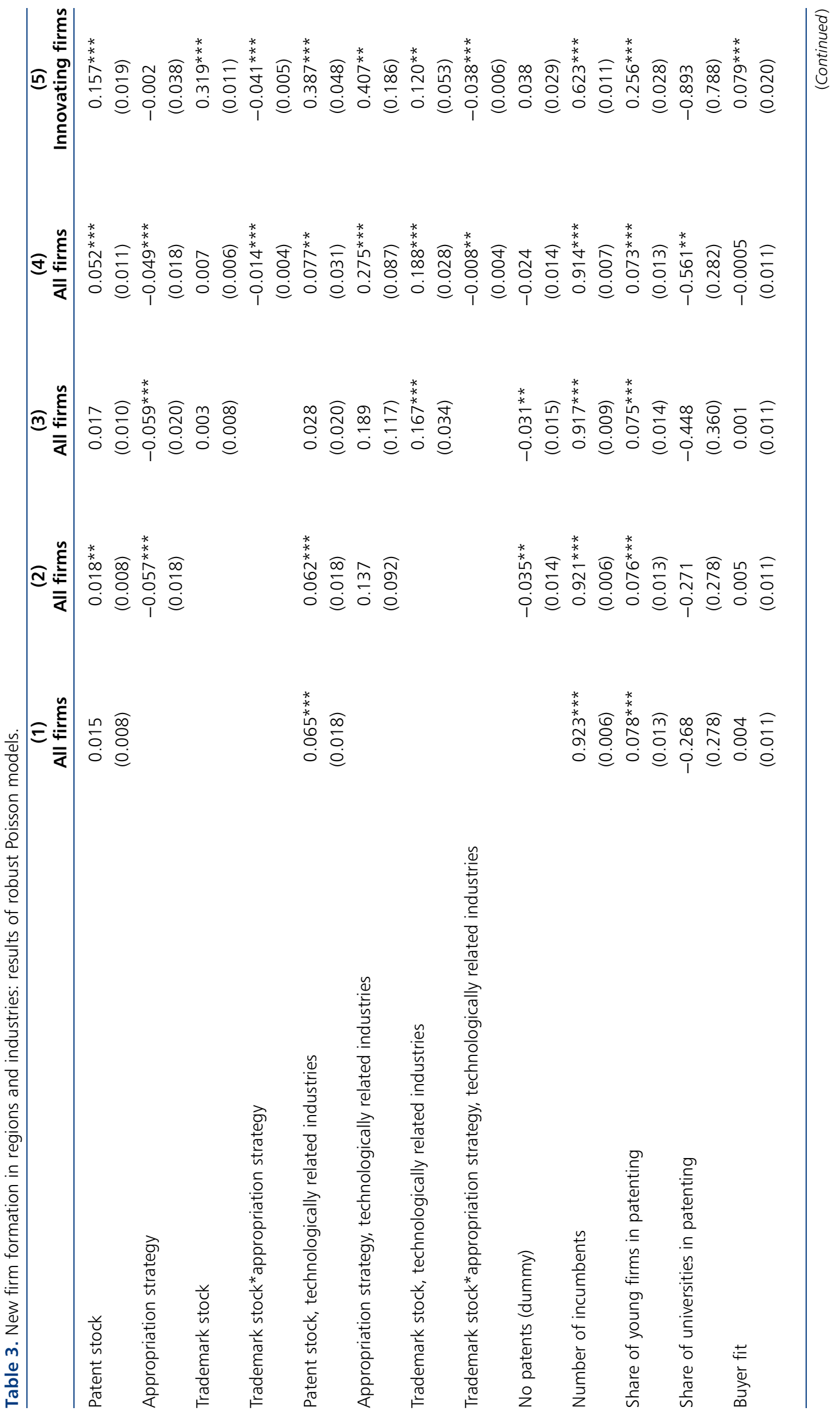




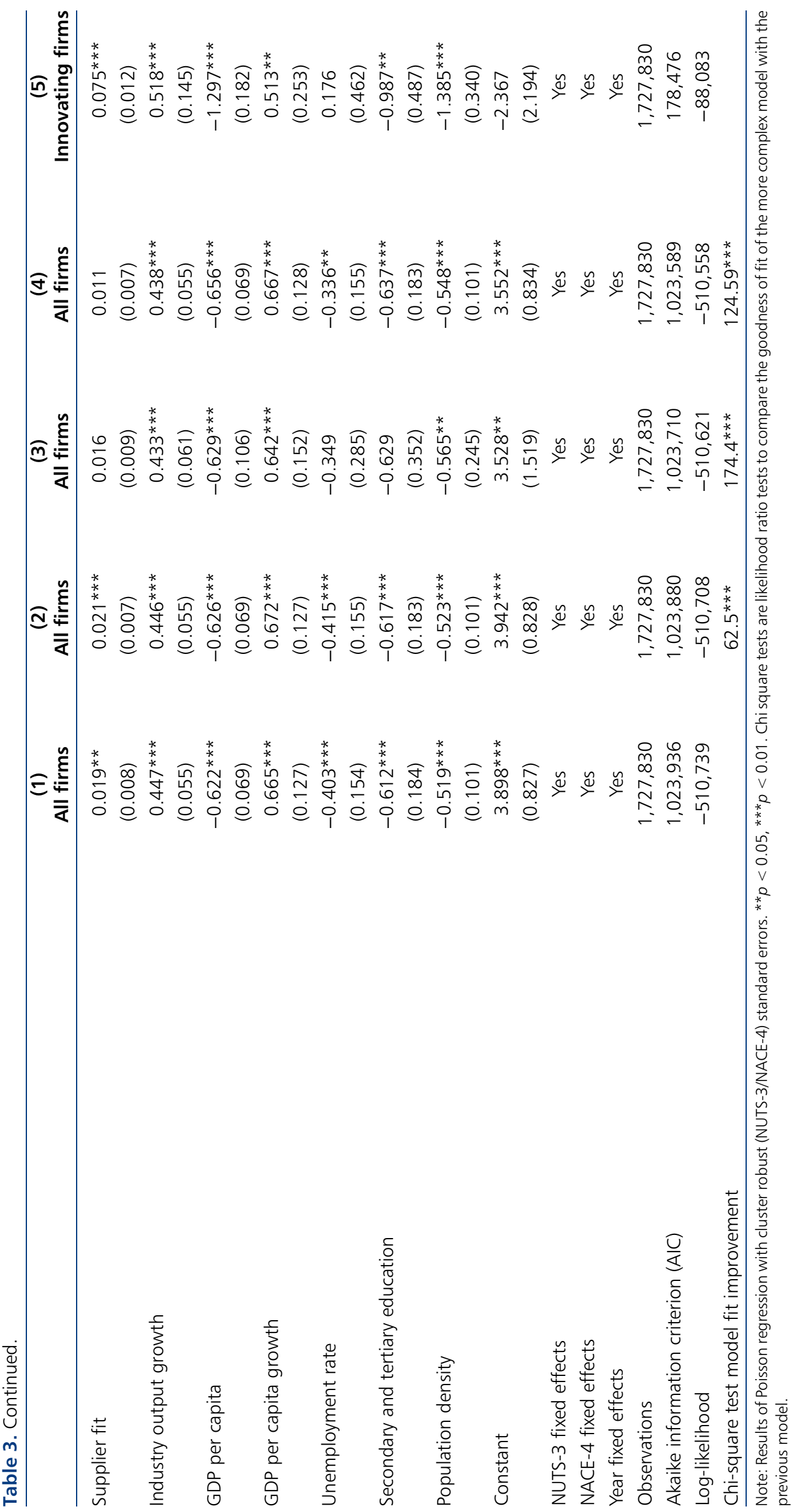




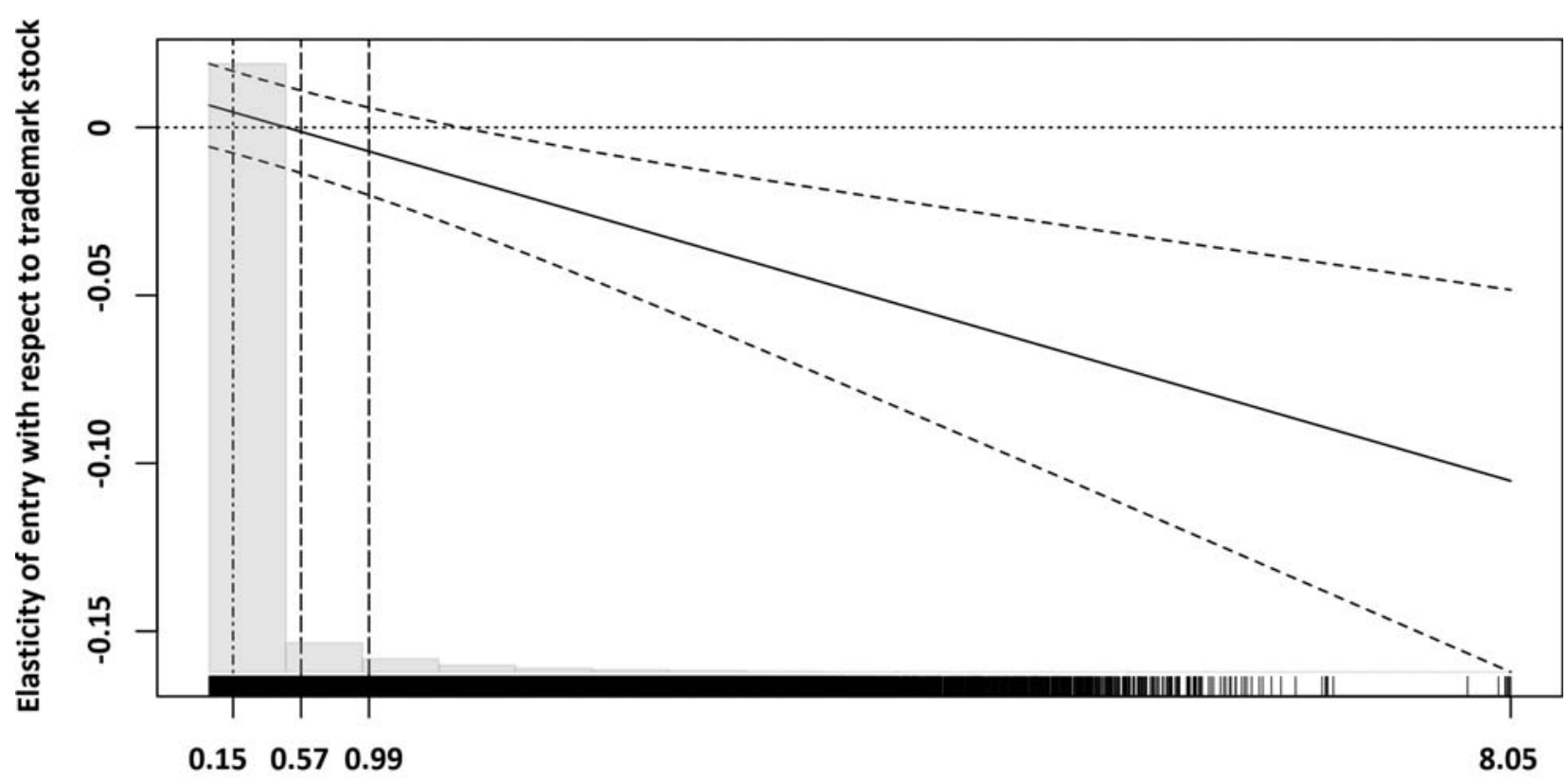

Appropriation strategy

Figure 1. Elasticity of new firm formation in industries and regions with respect to the trademark stock, as a function of incumbent appropriation strategy.

Note: The elasticity of new firm formation with respect to the trademark stock depending on incumbent appropriation strategy (the stock of self-cited patents) is shown. The dashed lines show the 95\% confidence interval. The dot-dashed vertical line shows the mean value of appropriation strategy. The dashed vertical lines show levels of appropriation strategy of 1 and 2 SD (standard deviations) above the mean. The histogram shows the distribution, and the rug plot (bottom of the graph) shows the individual observations of appropriation strategy. Appropriation strategy is the natural logarithm of the self-cited patent stock of incumbents.

we show that regionally embedded knowledge protected by trademarks may only translate into higher entry rates in the absence of a pronounced appropriation strategy of incumbent firms or when entrants do not directly compete with the trademarking incumbents. Under these circumstances, regional trademarking is more likely to trigger innovative entry rather than entry of non-innovating firms. Conversely, more intensive trademarking activity of incumbents strongly focused on technological knowledge-appropriation signals limited spillover opportunities and reduces entry. Thus our results reconcile the innovation based logic of trademarks with the notion in the industrial organization literature (Belleflamme \& Peitz, 2010; Lipczynski et al., 2005) that trademarks may be used strategically by incumbents and serve as an indicator of their commitment to raise entry barriers. If combined with an appropriation strategy, the effect of trademarking in the focal industry on new firm formation turns negative. Hence, appropriation strategies appear crucial to understand the strength and directionality of incumbent trademarks as knowledge related opportunities for entrants. Future studies could expand on our findings, further delineating contexts in which the use of trademark-based indicators can serve as a measure of innovation and spillover opportunities, and those were trademarks rather signal increased appropriation efforts of incumbents and their attempts to fend off competitors. In general, the interrelatedness between trademarks and patents in regional entrepreneurship and innovation will be a fruitful avenue for future research.

Our findings also add to the debate on the role of knowledge flows due to industry agglomeration and specialization on the one hand, and knowledge flows stemming from industry diversity on the other, in fostering innovation and regional growth (Beaudry \& Schiffauerova, 2009; Boschma, 2017; Boschma et al., 2015; Frenken et al., 2007; Jacobs, 1970; Kogler, 2017; van Oort, 2015). Patent stocks of incumbents in the industry facing the challenge of product market competition by new entrants generally have a weaker positive effect on entry than knowledge stocks in technologically related industries in which firms have fewer incentives to shield their knowledge or discourage entry. Our results point to the differential impact of appropriation strategies that limit knowledge spillovers and new firm formation in focal industries, but have less effect if they are employed by incumbents in technologically related industries. This suggests a qualification for the Marshallian type of knowledge externalities in distinct industries and clusters. Our findings on the importance of knowledge stocks in technologically related industries are consistent with the notion that related variety is crucial for innovation and growth (Frenken et al., 2007).

Our analysis is not without limitations, and we discuss the most salient ones. Although we assembled data at a very granular industry level (NACE four-digit), which is 


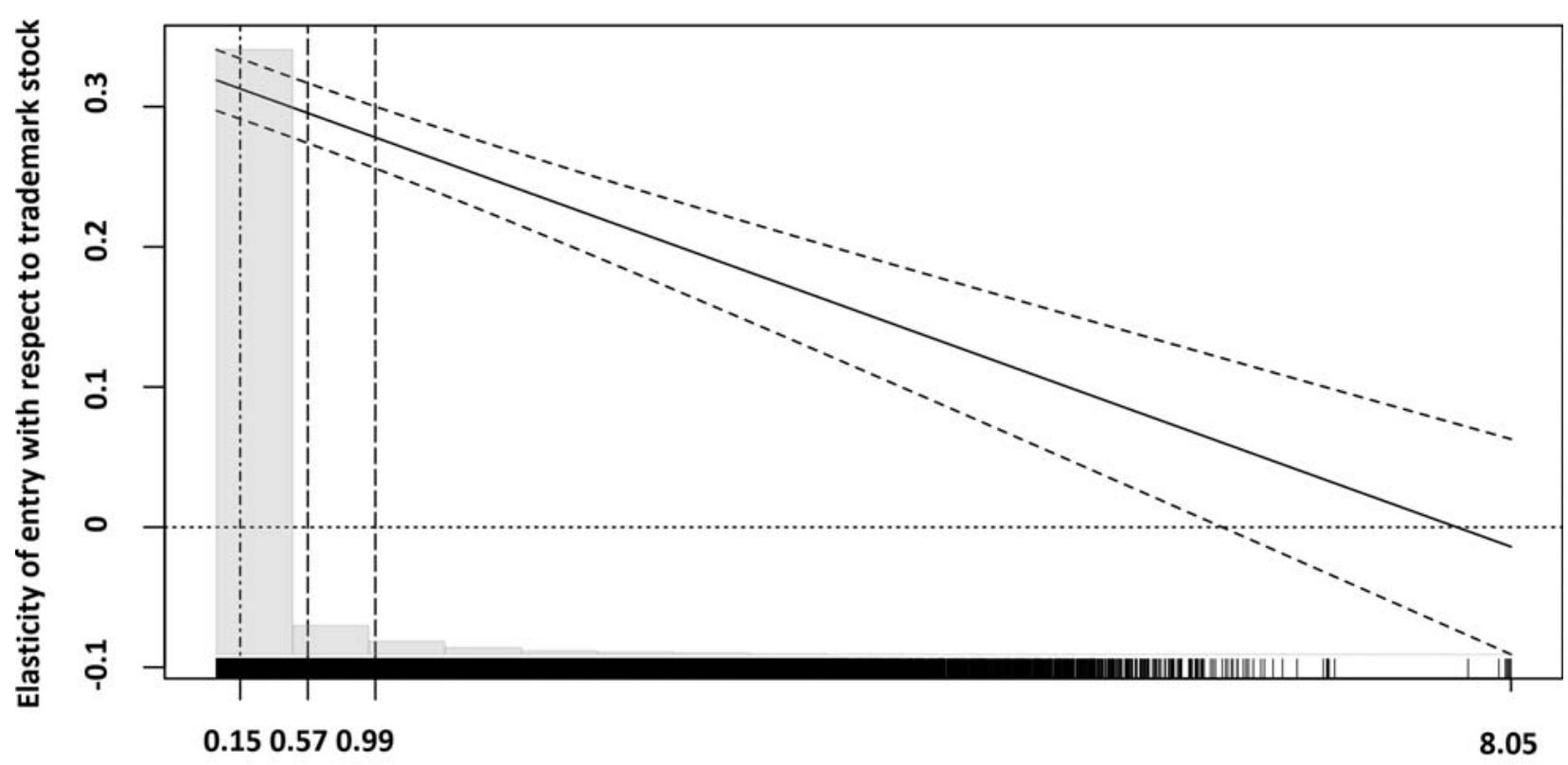

\section{Appropriation strategy}

Figure 2. Elasticity of innovating new firm formation in industries and regions with respect to the trademark stock, as a function of appropriation strategy.

Note: The elasticity of innovating new firm formation with respect to the trademark stock depending on incumbent appropriation strategy (the stock of self-cited patents) is shown. The dashed lines show the 95\% confidence interval. The dot-dashed vertical line shows the mean value of appropriation strategy. The dashed vertical lines show levels of appropriation strategy of 1 and 2 SD (standard deviations) above the mean. The histogram shows the distribution, and the rug plot (bottom of the graph) shows individual observations of appropriation strategy. Appropriation strategy is the natural logarithm of the self-cited patent stock of incumbents.

often seen as representing product markets (Bloom et al., 2013), some industries may be broad enough to include firms not competing directly. Even within NACE fourdigit industries there may exist separate market niches. Future work may examine the relationships under study at an even finer grained level. This would likely require the use of plant level data from the manufacturing census. Second, we note that the interaction variable between trademarks and appropriation strategy is based on the patent and trademark data aggregated over firms up to the NUTS-3/NACE-4 level. We do not observe the actual bundling of patents and trademarks at the level of the individual innovations. It would be interesting to verify our findings with more granular data on such bundling by incumbents.

Third, our data set covers the period 2002-09 and lacks an extension into more recent years, in which aspects of patents and trademarks have changed that could have repercussions for entry dynamics. On the one hand, Fleming et al. (2019) show that patenting is increasingly based on publicly funded scientific research, which may suggest a trend towards open innovation with increased knowledge spillovers and entry opportunities. On the other hand, there is strong evidence that in recent years entry and business dynamics may have declined due to an increasing concentration in patent intensive industries and a dominance of large tech incumbents with aggressive entrydeterring strategies (Akcigit \& Ates, 2021; Autor et al.,
2020, p. 703). This could suggest that the importance of knowledge-appropriation strategies in discouraging entry may have become even more prominent. Future research will be needed to disentangle the effect of these trends on entry dynamics.

Finally, spatial data samples such as ours require proper handling of the spatial dependence between observations. There are alternative estimation procedures to deal with this problem developed in the spatial econometrics literature (LeSage, 1999), but unfortunately they are not suitable for count data. We partially accommodated spatial dependence by weighting and aggregating patent and trademark stocks across adjacent regions. However, it is likely that some spatial correlation still remains in the standard errors of our model. Future work could benefit from further development in estimation techniques considered for count data.

\section{ACKNOWLEDGEMENTS}

The authors are grateful to the guest editors and anonymous reviewers for their valuable comments and suggestions regarding an earlier version of the manuscript. They also benefited from discussions and comments received at the EPIP 2018 Conference in Berlin and the Special Session on Trademarks in Space at the 5th Geography of Innovation Conference in Stavanger in January 2020. 


\section{DISCLOSURE STATEMENT}

No potential conflict of interest was reported by the authors.

\section{NOTES}

1. This includes standardization and harmonization, taking account of differences in names across countries, and removal of special characters and legal forms, among others.

2. Statistics on the top patenting and trademarking regions, aggregated across industries, can be obtained from the authors upon request.

3. There is no similar direct link between university patents and NACE industry as we can establish for firms based on their NACE codes in ORBIS.

4. Estimation of negative binomial models produces similar results.

\section{ORCID}

René A. Belderbos (D) http://orcid.org/0000-0002-40833387

Michat Kazimierczak (D) http://orcid.org/0000-00018796-6198

Micheline Goedhuys (D) http://orcid.org/0000-0003-42222106

\section{REFERENCES}

Aaker, D. (2007). Innovation: Brand it or lose it. California Management Review, 50(1), 8-24. https://doi.org/10.2307/ 41166414

Acs, Z. J., Audretsch, D. B., \& Lehmann, E. E. (2013). The knowledge spillover theory of entrepreneurship. Small Business Economics, 41(4), 757-774. https://doi.org/10.1007/s11187013-9505-9

Acs, Z. J., Braunerhjelm, P., Audretsch, D. B., \& Carlsson, B. (2009). The knowledge spillover theory of entrepreneurship. Small Business Economics, 32(1), 15-30. https://doi.org/10. 1007/s11187-008-9157-3

Agarwal, R., Audretsch, D., \& Sarkar, M. B. (2007). The process of creative construction: Knowledge spillovers, entrepreneurship, and economic growth. Strategic Entrepreneurship Journal, 1(34), 263-286. https://doi.org/10.1002/sej.36

Agarwal, R., Audretsch, D., \& Sarkar, M. B. (2010). Knowledge spillovers and strategic entrepreneurship. Strategic Entrepreneurship Journal, 4(4), 271-283. https://doi.org/10. $1002 /$ sej. 96

Agarwal, R., Ganco, M., \& Ziedonis, R. H. (2009). Reputations for toughness in patent enforcement: Implications for knowledge spillovers via inventor mobility. Strategic Management Journal, 30(13), 1349-1374. https://doi.org/10.1002/smj.792

Akcigit, U., \& Ates, S. (2021). Ten facts on declining business dynamism and lessons from endogenous growth theory. American Economic Journal: Macroeconomics, 13(1), 257-298. https://doi. org $/ 10.1257 / \mathrm{mac} .20180449$

Alcacer, J., \& Chung, W. (2014). Location strategies for agglomeration economies. Strategic Management Journal, 35(12), 17491761. https://doi.org/10.1002/smj.2186
Alcacer, J., \& Zhao, M. (2012). Local R\&D strategies and multilocation firms: The role of internal linkages. Management Science, 58(4), 734-753. https://doi.org/10.1287/mnsc.1110.1451

Arauzo-Carod, J. M., Liviano-Solis, D., \& Manjón-Antolín, M. (2010). Empirical studies in industrial location: An assessment of their methods and results. Journal of Regional Science, 50(3), 685-711. https://doi.org/10.1111/j.1467-9787.2009.00625.x

Arora, A., Bei, X., \& Cohen, W. M. (2016). Why firms trademark (or not): Evidence from the US trademark data. Academy of Management Proceedings, 2016(1), 17249. https://doi.org/10. 5465/ambpp.2016.17249abstract

Arora, A., Belenzon, S., Patacconi, A., \& Suh, J. (2020). The changing structure of American innovation: Some cautionary remarks for economic growth. Innovation Policy and the Economy, 20(1), 39-93. https://doi.org/10.1086/705638

Audretsch, D. B., \& Feldman, M. P. (1996). R\&D spillovers and the geography of innovation and production. The American Economic Review, 86(3), 630-640. http://www.jstor.org/stable/2118216

Audretsch, D. B., \& Fritsch, M. (2002). Growth regimes over time and space. Regional Studies, 36(2), 113-124. https://doi.org/10. 1080/00343400220121909

Audretsch, D. B., Keilbach, M. C., \& Lehmann, E. E. (2006). Entrepreneurship and economic growth. Oxford University Press.

Autor, D., Dorn, D., Katz, L. F., Patterson, C., \& Van Reenen, J. (2020). The fall of the labor share and the rise of superstar firms. The Quarterly Journal of Economics, 135(2), 645-709. https://doi.org/10.1093/qje/qjaa004

Basberg, B. L. (1987). Patents and the measurement of technological change: A survey of the literature. Research Policy, 16(2-4), 131141. https://doi.org/10.1016/0048-7333(87)90027-8

Beaudry, C., \& Schiffauerova, A. (2009). Who's right, Marshall or Jacobs? The localization versus urbanization debate. Research Policy, 38(2), 318-337. https://doi.org/10.1016/j.respol.2008.11.010

Belderbos, R., Cassiman, B., Faems, D., Leten, B., \& Van Looy, B. (2014). Co-ownership of intellectual property: Exploring the value-appropriation and value-creation implications of copatenting with different partners. Research Policy, 43(5), 841852. https://doi.org/10.1016/j.respol.2013.08.013

Belderbos, R., Ikeuchi, K., Fukao, K., Kim, Y. G., \& Kwon, H. U. (2013). Plant productivity dynamics and private and public RछD spillovers: Technological, geographic and relational proximity. FEB Working Paper No. MSI_1314.

Belderbos, R., \& Mohnen, P. (2020). Inter-sectoral and international $R E D$ spillovers. Working Papers No. 2020-047, United Nations University - Maastricht Economic and Social Research Institute on Innovation and Technology (MERIT).

Belderbos, R., Park, J. J., \& Carree, M. (2021). Do R\&D investments in weak IPR countries destroy market value? The role of internal linkages. Strategic Management Journal, 1-31. https://doi.org/10.1002/smj.3268

Belderbos, R., \& Somers, D. (2015). Do technology leaders deter inward R\&D investments? Evidence from regional R\&D location decisions in Europe. Regional Studies, 49(11), 18051821. https://doi.org/10.1080/00343404.2015.1018881

Belenzon, S. (2012). Cumulative innovation and market value: Evidence from patent citations. The Economic Journal, 122(559), 265-285. https://doi.org/10.1111/j.1468-0297.2011.02470.x

Belenzon, S., \& Schankerman, M. (2013). Spreading the word: Geography, policy, and knowledge spillovers. Review of Economics and Statistics, 95(3), 884-903. https://doi.org/10. 1162/REST_a_00334

Belleflamme, P., \& Peitz, M. (2010). Industrial organization: Markets and strategies. Cambridge University Press.

Block, J., Fisch, C., Ikeuchi, K., \& Kato, M. (2021). Trademarks as an indicator of regional innovation: Evidence from Japanese prefectures. Regional Studies, 1-20. https://doi.org/10.1080/ 00343404.2021 .1887843 
Block, J., Fisch, C. O., Hahn, A., \& Sandner, P. G. (2015). Why do SMEs file trademarks? Insights from firms in innovative industries. Research Policy, 44(10), 1915-1930. https://doi.org/10. 1016/j.respol.2015.06.007

Bloom, N., Schankerman, M., \& Van Reenen, J. (2013). Identifying technology spillovers and product market rivalry. Econometrica, 81(4), 1347-1393. https://doi.org/10.3982/ECTA9466

Boschma, R. (2017). Relatedness as driver of regional diversification: A research agenda. Regional Studies, 51(3), 351-364. https://doi. org/10.1080/00343404.2016.1254767

Boschma, R., Balland, P. A., \& Kogler, D. F. (2015). Relatedness and technological change in cities: The rise and fall of technological knowledge in US metropolitan areas from 1981 to 2010. Industrial and Corporate Change, 24(1), 223-250. https:// doi.org/10.1093/icc/dtu012

Bottazzi, L., \& Peri, G. (2003). Innovation and spillovers in regions: Evidence from European patent data. European Economic Review, 47(4), 687-710. https://doi.org/10.1016/S0014-2921(02)00307-0

Cameron, A. C., \& Trivedi, P. K. (2005). Microeconometrics: Methods and applications. Cambridge University Press.

Castaldi, C. (2019). On the market: Using trademarks to reveal organizational assets, strategies and capabilities. SSRN. http:// dx.doi.org/10.2139/ssrn.3255864

Castaldi, C. (2020). All the great things you can do with trademark data: Taking stock and looking ahead. Strategic Organization, 18 (3), 472-484. https://doi.org/10.1177/1476127019847835

Castaldi, C., Block, J., \& Flikkema, M. J. (2020). Editorial: Why and when do firms trademark? Bridging perspectives from industrial organisation, innovation and entrepreneurship. Industry and Innovation, 27(1-2), 1-10. https://doi.org/10.1080/13662716. 2019.1685376

Christensen, C. M. (2012). The innovator's dilemma: When new technologies cause great firms to fail. Harvard Business Review Press.

Crass, D. (2014). The impact of brand use on innovation performanceEmpirical results for Germany. Discussion Paper, pp. 14-119. ZEW - Centre for European Economic Research.

De Faria, P., \& Sofka, W. (2010). Knowledge protection strategies of multinational firms-A cross-country comparison. Research Policy, 39(7), 956-968. https://doi.org/10.1016/j.respol.2010.03.005

Decker, R., Haltiwanger, J., Jarmin, R., \& Miranda, J. (2014). The role of entrepreneurship in US job creation and economic dynamism. Journal of Economic Perspectives, 28(3), 3-24. https://doi. org/10.1257/jep.28.3.3

Dosi, G. (1988). Sources, procedures, and microeconomic effects of innovation. Journal of Economic Literature, 1120-1171. https:// www.jstor.org/stable/2726526

Drivas, K. (2020). The role of technology and relatedness in regional trademark activity. Regional Studies, 1-14. https://doi.org/10. 1080/00343404.2020.1808883

Dumais, G., Ellison, G., \& Glaeser, E. L. (2002). Geographic concentration as a dynamic process. Review of Economics and Statistics, 84(2), 193-204. https://doi.org/10.1162/ 003465302317411479

Fairlie, R. W., \& Fossen, F. M. (2018). Opportunity versus necessity entrepreneurship: Two components of business creation. CESifo Working Paper Series No. 6854. https://ssrn.com/abstract $=3140340$

Fleming, L., Greene, H., Li, G., Marx, M., \& Yao, D. (2019). Government-funded research increasingly fuels innovation. Science, 364(6446), 1139-1141. https://doi.org/10.1126/science. aaw 2373

Flikkema, M., Castaldi, C., de Man, A. P., \& Seip, M. (2019). Trademarks' relatedness to product and service innovation: A branding strategy approach. Research Policy, 48(6), 1340-1353. https://doi.org/10.1016/j.respol.2019.01.018

Flikkema, M., De Man, A. P., \& Castaldi, C. (2014). Are trademark counts a valid indicator of innovation? Results of an in-depth study of new Benelux trademarks filed by SMEs. Industry and
Innovation, 21(4), 310-331. https://doi.org/10.1080/13662716. 2014.934547

Frenken, K., Van Oort, F., \& Verburg, T. (2007). Related variety, unrelated variety and regional economic growth. Regional Studies, 41(5), 685-697. https://doi.org/10.1080/0034340060 1120296

Geroski, P. (1991). Market dynamics and entry. Basil Blackwell.

Geroski, P. A. (1995). What do we know about entry? International Journal of Industrial Organization, 13(4), 421-440. https://doi. org/10.1016/0167-7187(95)00498-X

Glaeser, E. L., Kallal, H. D., Scheinkman, J. A., \& Shleifer, A. (1992). Growth in cities. Journal of Political Economy, 100(6), 1126-1152. https://doi.org/10.1086/261856

Glaeser, E. L., \& Kerr, W. R. (2009). Local industrial conditions and entrepreneurship: How much of the spatial distribution can we explain? Journal of Economics E Management Strategy, 18(3), 623-663. https://doi.org/10.1111/j.1530-9134.2009. 00225.x

Gotsch, M., \& Hipp, C. (2012). Measurement of innovation activities in the knowledge-intensive services industry: A trademark approach. The Service Industries Journal, 32(13), 2167-2184. https://doi.org/10.1080/02642069.2011.574275

Greenhalgh, C., \& Rogers, M. (2012). Trademarks and performance in services and manufacturing firms: Evidence of Schumpeterian competition through innovation. Australian Economic Review, 45 (1), 50-76. https://doi.org/10.1111/j.1467-8462.2011.00665.x

Greenstone, M., Hornbeck, R., \& Moretti, E. (2010). Identifying agglomeration spillovers: Evidence from winners and losers of large plant openings. Journal of Political Economy, 118(3), 536598. https://doi.org/10.1086/653714

Griffith, R., Redding, S., \& Simpson, H. (2009). Technological catch-up and geographic proximity. Journal of Regional Science, 49(4), 689-720. https://doi.org/10.1111/j.1467-9787.2009. 00630.x

Guellec, D., \& Van Pottelsberghe de la Potterie, B. (2004). From $\mathrm{R} \& \mathrm{D}$ to productivity growth: Do the institutional settings and the source of funds of R\&D matter? Oxford Bulletin of Economics and Statistics, 66(3), 353-378. https://doi.org/10. 1111/j.1468-0084.2004.00083.x

Guellec, D., \& Van Pottelsberghe de la Potterie, B. (2007). The economics of the European patent system: IP policy for innovation and competition. Oxford University Press.

Hall, B. H., Jaffe, A., \& Trajtenberg, M. (2005). Market value and patent citations. RAND Journal of Economics, 36(1), 16-38. https://doi.org/10.3386/w7741

Hilbe, J. M. (2014). Modeling count data. Cambridge University Press.

Jacobs, J. (1970). The economy of cities. Vintage.

Jaffe, A. (1986). Technological opportunity and spillovers of R\&D: Evidence from firms' patents, profits, and market value. American Economic Review, 76(5), 984-1001. https://doi.org/10.3386/ w1815

Jaffe, A., Trajtenberg, M., \& Henderson, R. (1993). Geographic localization of knowledge spillovers as evidenced by patent citations. The Quarterly Journal of Economics, 108(3), 577-598. https://doi.org/10.2307/2118401

Jofre-Monseny, J., Marín-López, R., \& Viladecans-Marsal, E. (2011). The mechanisms of agglomeration: Evidence from the effect of inter-industry relations on the location of new firms. Journal of Urban Economics, 70(2-3), 61-74. https://doi.org/10. 1016/j.jue.2011.05.002

Kim, M. (2015). Geographic scope, isolating mechanisms, and value appropriation. Strategic Management Journal, 37(4), 623-815. https://doi.org/10.1002/smj.2356

Knoben, J., Ponds, R., \& van Oort, F. (2011). Employment from new firm formation in the Netherlands: Agglomeration economies and the knowledge spillover theory of entrepreneurship. 
Entrepreneurship and Regional Development, 23(3-4), 135-157. https://doi.org/10.1080/08985620903183736

Kogler, D. F. (2017). Relatedness as driver of regional diversification: A research agenda-a commentary. Regional Studies, 51(3), 365-369. https://doi.org/10.1080/00343404. 2016.1276282

Lee, S. Y., Florida, R., \& Acs, Z. (2004). Creativity and entrepreneurship: A regional analysis of new firm formation. Regional Studies, 38(8), 879-891. https://doi.org/10.1080/00343400 42000280910

LeSage, J. P. (1999). The theory and practice of spatial econometrics. University of Toledo.

Leten, B., Belderbos R., \& van Looy, B. (2016). Entry and technological performance in new technology domains: Technological opportunities, technology competition and technological relatedness. Journal of Management Studies, 53(8), 1257-1291. https://doi.org/10.2139/ssrn.2782362

Levin, R. C., Klevorick, A. K., Nelson, R. R., Winter, S. G., Gilbert, R., \& Griliches, Z. (1987). Appropriating the returns from industrial research and development. Brookings Papers on Economic Activity, 1987(3), 783-831. https://doi.org/10.2307/ 2534454

Lipczynski, J., Wilson, J. O., \& Goddard, J. A. (2005). Industrial organization: Competition, strategy, policy. Pearson Education.

Llerena, P., \& Millot, V. (2020). Are two better than one? Modelling the complementarity between patents and trademarks across industries. Industry and Innovation, 27(1-2), 52-79. https://doi.org/10.1080/13662716.2019.1688137

Louçã, F., \& Mendonça, S. (2002). Steady change: The 200 largest US manufacturing firms throughout the 20th century. Industrial and Corporate Change, 11(4), 817-845. https://doi.org/10.1093/ icc/11.4.817

Lychagin, S., Pinkse, J., Slade, M. E., \& Reenen, J. V. (2016). Spillovers in space: Does geography matter? The Journal of Industrial Economics, 64(2), 295-335. https://doi.org/10.1111/ joie. 12103

Magerman, T., Van Looy, B., \& Song, X. (2006). Data production methods for harmonized patent statistics: Patentee name harmonization. Office for Official Publications of the European Communities.

Malerba, F. (2007). Innovation and the dynamics and evolution of industries: Progress and challenges. International Journal of Industrial Organization, 25(4), 675-699. https://doi.org/10. 1016/j.ijindorg.2006.07.005

Maskell, P., \& Malmberg, A. (1999). Localised learning and industrial competitiveness. Cambridge Journal of Economics, 23(2), 167-185. https://doi.org/10.1093/cje/23.2.167

Mendonça, S., Pereira, T. S., \& Godinho, M. M. (2004). Trademarks as an indicator of innovation and industrial change. Research Policy, 33(9), 1385-1404. https://doi.org/10.1016/j. respol.2004.09.005

Nelson, R. R., \& Winter, S. G. (1982). An evolutionary theory of economic change. Harvard University Press.
Orsenigo, L. (2018). Industrial evolution and disruptive innovation: Theories, evidence and perspectives. In Linnhoff-Popien, C., Schneider, R., \& Zaddach, M. (Eds.), Digital marketplaces unleashed (pp. 205-219). Springer.

Plummer, L. A., \& Acs, Z. J. (2014). Localized competition in the knowledge spillover theory of entrepreneurship. Journal of Business Venturing, 29(1), 121-136. https://doi.org/10.1016/j. jbusvent.2012.10.003

Qian, H., Acs, Z. J., \& Stough, R. R. (2013). Regional systems of entrepreneurship: The nexus of human capital, knowledge and new firm formation. Journal of Economic Geography, 13(4), 559-587. https://doi.org/10.1093/jeg/lbs009

Rujas, J. (1999). Trademarks: Complementary to patents. World Patent Information, 21(1), 35-39. https://doi.org/10.1016/ S0172-2190(99)00023-X

Sáiz, P., \& Zofío, J. L. (2021). The making and consolidation of the first national trademark system: The diffusion of trademarks across Spanish regions, 1850-1920. Regional Studies, 1-20. https://doi.org/10.1080/00343404.2021.1887472

Sandner, P. G., \& Block, J. (2011). The market value of R\&D, patents, and trademarks. Research Policy, 40(7), 969-985. https://doi.org/10.1016/j.respol.2011.04.004

Schautschick, P., \& Greenhalgh, C. (2016). Empirical studies of trade marks - The existing economic literature. Economics of Innovation and New Technology, 25(4), 358-390. https://doi. org/10.1080/10438599.2015.1064598

Scotchmer, S. (2004). Innovation and incentives. MIT Press.

Spulber, D. F. (2006). Entry barriers and entry strategies. In A. E. Burke (Ed.), Modern perspectives on entrepreneurship (pp. 6990). Senate Hall.

Teece, D. J. (1986). Profiting from technological innovation: Implications for integration, collaboration, licensing and public policy. Research Policy, 15(6), 285-305. https://doi.org/10. 1016/0048-7333(86)90027-2

Thoma, G. (2015). Trademarks and the patent premium value: Evidence from medical and cosmetic products. World Patent Information, 41, 23-30. https://doi.org/10.1016/j.wpi.2015.02.003

Tsvetkova, A. (2015). Innovation, entrepreneurship, and metropolitan economic performance: Empirical test of recent theoretical propositions. Economic Development Quarterly, 29(4), 299-316. https://doi.org/10.1177/0891242415581398

van Oort, F. G. (2015). Unity in variety? Agglomeration economics beyond the specialization-diversity controversy. In C. Karlsson, M. Andersson, \& T. Norman (Eds.), Handbook of research methods and applications in economic geography (pp. 259-271). Edward Elgar.

Winter, S. G. (1984). Schumpeterian competition in alternative technological regimes. Journal of Economic Behavior $\mathcal{E}^{\circ}$ Organization, 5(3-4), 287-320. https://doi.org/10.1016/01672681(84)90004-0

Zhao, M. (2006). Conducting R\&D in countries with weak intellectual property rights protection. Management Science, 52(8), 1185-1199. https://doi.org/10.1287/mnsc.1060.0516 